\title{
MARRIAGE INSURANCE TAKING INTO ACCOUNT DEPENDENCE AND DIVORCES
}

ŚLĄSKI

PRZEGLĄD

STATYSTYCZNY

Nr 16(22)

\author{
Stanisław Heilpern
}

Wrocław University of Economics

e-mail: stanislaw.heilpern@ue.wroc.pl

ISSN 1644-6739

ORCID: 0000-0001-5173-6067

e-ISSN 2449-9765

DOI: $10.15611 /$ sps.2018.16.02

JEL Classification: C12, C18, G22, J12

\begin{abstract}
The paper is devoted to marriage insurance contracts allowing dependence between lifetimes of spouses. The dependence structure is described by the five stage Markov process. One state concerns divorce, which was not investigated in previous papers. It makes this paper more realistic. The transition probabilities are derived and the Markov forces of transition are estimated. The four pensions of spouses: the joint-life and last survival annuities, the widow pension and reversionary annuity are introduced and studied. A real example based on the data from Lower Silesia during 2011 is investigated. The values of these annuities are computed and analyzed. The five different cases are studied. The impact of the age of spouses and the duration of annuities on the values of annuities is investigated. A case when the reversionary annuity with the reduction parameter $R=2 / 3$ is analyzed. A comparison with a non-divorce case is considered.
\end{abstract}

Keywords: marriage insurance, dependence, Markov chain, annuities, divorce.

\section{Introduction}

The subject of paper is dependent marriage insurance contracts allowing dependence between the lifetimes of the spouses. This is a generalization of the author's previous work [Heilpern 2011; 2015]. The dependence of the spouses lifetime was allowed and the four-state Markov process were investigated in these papers. In our paper we added the fifth state concerning divorce. Divorce was not mentioned and they was not considered in previous papers, not only by the authors but in other papers, for instance in [Denuit et al. 2001]. This makes our paper more realistic.

Section 2 is devoted to the Markov model. We introduce the basic notions connected with the life insurance contracts and present the fifth state Markov model including the state concerning divorce. The transition probabilities of this model are derived and the Markov forces of transition are estimated. In Section 3 we introduce and

\footnotetext{
* The project was funded by the National Science Centre allocated on the basis of decision no. DEC-2013/09/B/HS4/00490.
} 
investigate the four pensions of spouses: the joint-life and last survival annuities, the widow pension and reversionary annuity.

The example based on data from Lower Silesia during 2011 is investigated in Section 4. This data are derived from Polish Central Statistical Office. We compute and analyze the values of the join-life, the widow, the last-survival and the reversionary annuity for reduction factor $R=2 / 3$. We study five cases. First, we investigate the values of such four annuities for different ages of spouses, when the wife and husband are of the same age. Second, we analyze the values of these four annuities for 50year-old spouses for different durations of annuities. Next, we consider the case when the wife is 60 years old and the age of the husband is changed. We investigate the values of reversionary annuity for different values of coefficient $R$ in other cases. The last case is devoted to the analysis of the influence of the age difference between the wife and husband on the values of these annuities. We also consider a comparison with the non-divorce case.

\section{Markov model}

First we introduce the main notions connected with the life insurance contracts. Let $T_{x}^{M}$ and $T_{y}^{W}$ be the remaining lifetimes of a $x$-year-old husband and $y$-year-old wife. These random variables take value in $[0$, $\left.w_{x}^{M}\right]$ and $\left[0, w_{y}^{W}\right]$, where $w_{x}^{M}$ (resp. $w_{y}^{W}$ ) is the difference between the limit age of man (resp. woman) and $x$ (resp. y). The appropriate Life Tables limit the ages $w_{x}^{M}=w_{y}^{W}=100$ (sometimes 110). The survival functions of $T_{x}^{M}$ and $T_{y}^{W}$ are denoted by [Gerber 1995]

$$
{ }_{t} p_{x}^{M}=P\left(T_{x}^{M}>t\right) \text { and }{ }_{t} p_{y}^{W}=P\left(T_{y}^{W}>t\right) .
$$

These survival functions can be derived using the forces of mortalities $\mu_{x}^{M}$ and $\mu_{y}^{W}$, for instance

$$
{ }_{t} p_{x}^{M}=\exp \left(-\int_{0}^{t} \mu_{x+s}^{M} d s\right)
$$

In practice we can compute these probabilities from lifetables:

$$
{ }_{t} p_{x}^{M}=\frac{l_{x+l}^{M}}{l_{x}^{M}}
$$

where $l_{x}^{M}$ is the number of men who survive to ages $x$. 
We introduce and investigate the Markov model of lifetime of the spouses based on the stationary Markov chain in this section. This Markov chain has five states (see Figure 1) and it is the generalization STATYSTYCZNY of the model investigated in [Wolthuis, Van Hoeck 1986; Wolthuis 1994; Norberg 1989; Denuit et al. 2001]. It takes into account divorce.

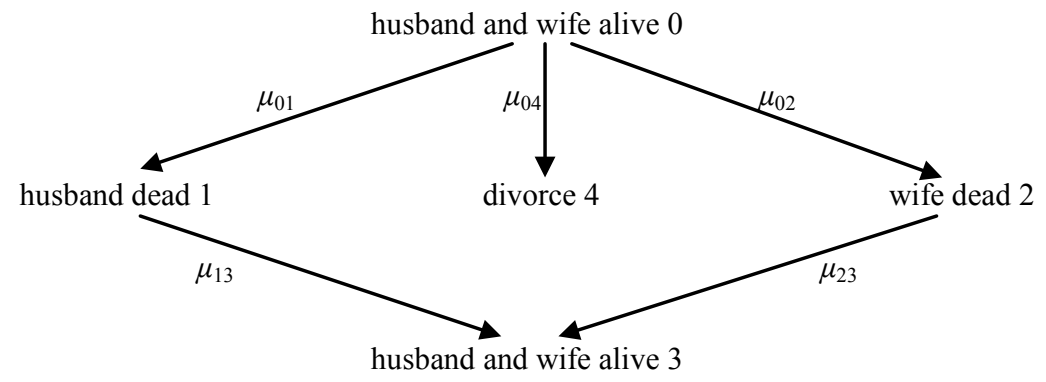

Fig. 1. Markov model

Source: own elaboration.

Now, we assume that the husband is $x$ years old and the wife is $y$ years old. Let $X(t)$ be the process which describes the above Markov model. We assume that $X(t)$ is the nonhomogeneous Markov chain [Wolthuis, Van Hoeck 1986; Wolthuis 1994; Norberg 1989; Denuit et al. 2001]. Then $X(t)=i$ means that the spouses are in the state $i$ at moment $t$. Let $p_{i j}(t, s)$ be the transition probabilities, the conditional probability that the couple is in state $j$ at time $s$, given that it was in state $i$ at time $t$, where $i, j=0,1,2,3,4$. The Markov forces of transition $\mu_{i j}(t)$ from state $i$ to state $j$ is defined by the following formula [Denuit et al. 2001]:

$$
\mu_{i j}(t)=\lim _{\Delta t \rightarrow 0} \frac{p_{i j}(t, t+\Delta t)}{\Delta t} .
$$

We can obtain the transition probability using the forces of transition in the following way: [Denuit et al. 2001]

$$
\begin{gathered}
p_{00}(t, s)=\exp \left(-\int_{t}^{s}\left(\mu_{01}(u)+\mu_{02}(u)+\mu_{04}(u)\right) d u\right), \\
p_{i i}(t, s)=\exp \left(-\int_{t}^{s}\left(\mu_{i 3}(u) d u\right), \text { where } i=1,2,\right. \\
p_{0 i}(t, s)=\int_{t}^{s} p_{00}(t, u) \mu_{0 i}(u) p_{i i}(u, s) d u, \text { where } i=1,2,4 .
\end{gathered}
$$


So, the probability that the spouses are alive to time $t$, i.e. the $\mathrm{Nr}$ 16(22) process is in the state 0 , is equal $p_{00}(0, t)$.

If we want to use the Markov model to derive the marriage annuities, we must estimate the Markov forces of transition $\mu_{i j}(t)$. We ought to use the Nelson-Aalen estimator to this end [Denuit et al. 2001]. It is based on the cumulative function

$$
\Omega_{i j}(t)=\int_{0}^{t} \mu_{i j}(u) d u
$$

where $i=0,1,2, j=1,2,3,4$ and the increments $\Delta \Omega_{i j}(t)=\Omega_{i j}(t+1)-$ $\Omega_{i j}(t)$. The estimator $\Delta \hat{\Omega}_{0 j}$ is equal to

$$
\Delta \hat{\Omega}_{i j}(t)=\frac{\Delta L_{i j}(t)}{L_{i}(t+1)-L_{i}(t)}\left(\ln L_{i}(t+1)-\ln L_{i}(t)\right) .
$$

The symbol $\Delta L_{i j}(t)$ represents the number of transitions from state $i$ to state $j$ observed for $t$-old individuals and $L_{i}(t)$ is the number of couples in state $i$ at time $t$ [Wolthuis 1994; Denuit et al. 2001].

Now we assume that forces of transition $\mu_{i j}(\cdot)$ are constant for each year of age i.e.

$$
\mu_{i j}(k+\tau)=\mu_{i j}(k),
$$

for $0 \leq \tau<1$ and $k=0,1, \ldots$ Then we obtain:

$$
\begin{gathered}
p_{00}(h, k)=\exp \left(-\sum_{j=h}^{k}\left(\mu_{01}(j)+\mu_{02}(j)+\mu_{04}(j)\right)\right) \\
p_{i i}(h, k)=\exp \left(-\sum_{j=h}^{k} \mu_{i 3}\right), \\
p_{0 i}(k, k+1)=\frac{\mu_{0 i}(k)\left(\exp \left(-\mu_{01}(k)-\mu_{02}(k)-\mu_{04}(k)\right)-\exp \left(-\mu_{i 3}(k)\right)\right)}{\mu_{i 3}(k)-\mu_{01}(k)-\mu_{02}(k)-\mu_{04}(k)},
\end{gathered}
$$

where $i=1,2$ and

$$
\Delta \Omega_{i j}(k)=\int_{k}^{k+1} \mu_{i j}(u) d u=\mu_{i j}(k) .
$$

Therefore under the above assumption we can treat the increments $\Delta \Omega_{i j}(k)$ as the estimator of the force of transition $\mu_{i j}(k)$.

In the case of independent lifetimes of the spouses we have the following relations [Wolthuis 1994]: 


$$
\mu_{01}(t)=\mu_{23}(t)=\mu_{x+t}^{M}, \mu_{02}(t)=\mu_{13}(t)=\mu_{y+t}^{K} .
$$

When the lifetimes are positively correlated we obtain

$$
\mu_{01}(t)<\mu_{23}(t) \text { and } \mu_{02}(t)<\mu_{13}(t) .
$$

Thus the authors in [Denuit et al. 2001] considered the dependence of lifetimes and investigated the following relations between the forces of mortalities of spouses and the Markov forces of transition:

$$
\begin{array}{cc}
\mu_{01}(t)=\left(1-\alpha_{01}\right) \mu_{x+t}^{M}, & \mu_{23}(t)=\left(1+\alpha_{23}\right) \mu_{x+t}^{M}, \\
\mu_{02}(t)=\left(1-\alpha_{02}\right) \mu_{y+t}^{K}, & \mu_{13}(t)=\left(1+\alpha_{13}\right) \mu_{y+t}^{K},
\end{array}
$$

where $\alpha_{i j} \geq 0$ and $\alpha_{0 j}<1$. But they studied the smaller model, which did not take into account the divorces. We cannot obtain the forces of transition $\mu_{04}(t)$ in such a way. We may use relation (2) in this case.

\section{Pensions}

We introduce and investigate the four pensions of spouses: joint-life, last survival, widows and reversionary annuity for $x$ year old husband and $y$ year old woman. In the case of the joint-life status the benefit is paid only until the death of the first spouse or until the divorce. We assume that all annuities are suppressed with the occurrence of divorce. The probability of a joint-life status ${ }_{t} p_{x y}$ surviving to time $t$ is equal the probability that the spouses are in state 0 at moment $t$, i.e. $X(t)=0$ and

$$
{ }_{t} p_{x y}=P(X(t)=0)=p_{00}(0, t) .
$$

The $n$-year joint-life survival annuities pays 1 unit at the end of years $1,2, \ldots, n$, as long as both spouses are together. So the actuarial value of this pension is equal [Gerber 1995; Denuit et al. 2001] to

$$
a_{x y ; \bar{n} \mid}=\sum_{k=1}^{n} v_{k}^{k} p_{x y},
$$

where $v=(1+\xi)^{-1}$ is the discount factor and $\xi$ is the annual effective rate. In practice we should assume that $n \leq \min \left(w_{x}, w_{y}\right)$.

In the case of the last survival status the benefit is paid as long either spouse survives or until the divorce. The probability of a last 
survival status ${ }_{t} p_{\overline{x y}}$ surviving to time $t$ is equal to the probability that

$\mathbf{N r}$ 16(22) the spouses are in state 0,1 or 2, i.e.

$$
{ }_{t} p_{\overline{x y}}=P(X(t)=1)+P(X(t)=2)+P(X(t)=0) .
$$

First, we investigate pension $a_{x|y, \bar{n}|}^{W}$, when the payments start with the husband's death and terminate with the death of his wife, or they end after $n$ years from the contract. The process is in the state 1 in this case. This pension takes the following value [Denuit et al. 2001]:

$$
a_{x|y ; \bar{n}|}^{W}=\sum_{k=0}^{n-1} p_{00}(0, k) p_{01}(k, k+1) \sum_{j=0}^{n-k-1} p_{11}(k+1, k+1+j) v^{k+1+j} .
$$

When $n=\infty$, in practice $n=w_{y}$, we obtain the so-called widows pension. In the similar way we introduce pension $a_{y \mid x ; \bar{n}}^{M}$, when the payments starts with the wife's death, i.e. the process is in the state 2 . The actuarial value of this pension is equal to:

$$
a_{y|x ; \bar{n}|}^{M}=\sum_{k=0}^{n-1} p_{00}(0, k) p_{02}(k, k+1) \sum_{j=0}^{n-k-1} p_{22}(k+1, k+1+j) v^{k+1+j} .
$$

The $n$-year last survival annuities $a_{\overline{x y} ; \bar{n} \mid}$ takes the form:

$$
a_{\overline{x y} ; \bar{n} \mid}=a_{x|y ; \bar{n}|}^{W}+a_{y|x ; \bar{n}|}^{M}+a_{x y ; \bar{n} \mid} .
$$

The last pension is the reversionary annuity [Luciano, Spreeuw, Vigna 2016]. It pays for $n$ years unit as long as both spouses are together and it pays a reduction fraction $R$ of it when only one member of the couple is alive. In practice, the reduction factor $R$ is often equal to 0.5 or $2 / 3$. This pension is described by the following formula:

$$
a_{x, y, \bar{n} \mid}^{R}=R a_{x|y ; \bar{n}|}^{W}+R a_{y|x ; \bar{n}|}^{M}+a_{x y ; \bar{n} \mid} .
$$

For reduction factor $R=0$ we obtain $n$-year joint-life survival annuities and for $R=1$ we have $n$-year last survival annuities.

\section{Example}

Now we derive the actuarial values of the pensions introduced in Section 3 using the real data from Lower Silesia during 2011 from the Polish Central Statistical Office (GUS). We compute the Markov 
forces of transition $\mu_{0 j}(t)$, for $j=1,2,4$, using the method described in

Section 3, based on the increments $\Delta \Omega_{0 j}(t)$. The numerator $\Delta L_{01}(t)$ of (1) is the number of $t$-year old married men dying during 2011 and it STATYSTYCZNY is directly available from GUS. The denominator $L_{0}(t+1)-L_{0}(t)$ is equal to [Denuit et al. 2001; Heilpern 2011]

- the number $t$-year old married men getting married during 2011,

- $\quad$ minus the number $t$-year old married men dying during 2011 ,

- minus the number such men getting divorced during 2011,

- minus the number of $t$-year old widowers whose wives died during 2011.

This data is available, too. $L_{0}(t)$ is the number of $t$-year old married men at January 1, 2011.

The numerator $\Delta L_{13}(t)$ is the number of $t$-year old widows dying during 2011 and the denominator is

- the number $t$-year old widows whose husband died during 2011

- minus the number of $t$-year old widows dying during 2011

- minus the number of $t$-year old widows getting married during 2011.

$L_{1}(t)$ is the number of $t$-year old widows at January 1, 2011.

We estimate the increments $\Delta \Omega_{02}(t)$ and $\Delta \Omega_{23}(t)$ in a similar way by switching the roles of the two spouses. We obtain the following parameters

$$
a_{01}=0.0856, a_{02}=0.13820, a_{13}=-0.06024, a_{23}=0.24786 .
$$

We see that the lifetimes of spouses are positively dependent.

We obtain the Markov forces of transition $\mu_{04}(t)$ using (2) and compute $\Delta \Omega_{04}(t)$ in the similar way as $\Delta \Omega_{02}(t)$. The numerator $\Delta L_{04}(t)$ is the number of wives getting divorced during 2011 in this case.

The values of the Markov forces of transition $\mu_{13}(t)$ and $\mu_{23}(t)$ do not depend on the number of divorces. We obtain them using equations (3) and the values of the forces of mortalities of spouses. The values of these forces of mortalities $\mu_{x}^{M}$ and $\mu_{y}^{K}$ are available from GUS data.

Now we will analyze the value of four pensions: the joint-life, the widow, the last-survival and the reversionary annuity for reduction factor $R=2 / 3$, presented in Section 3. Table 1 contains the values of such four pensions for different ages of spouses. We assume the same age of the husband and wife in this case and $n=\infty$. We also present these values in Figure 2. We can see that the values of three pensions: the joint-life, the last-survival and the reversionary decrease with the 
Table 1. The values of four annuities for different ages of spouses

$\operatorname{Nr}$ 16(22)

\begin{tabular}{|l|c|c|c|c|c|}
\hline \multirow{2}{*}{$x=y$} & \multicolumn{2}{|c|}{ Joint-life } & \multirow{2}{*}{ Last-survival } & \multirow{2}{*}{ Widow } & \multirow{2}{*}{ Reversionary } \\
\cline { 2 - 3 } & with divorces & without & & & \\
\hline 40 & 19.4001 & 21.7685 & 22.4719 & 2.2644 & 21.4480 \\
\hline 45 & 18.7662 & 20.1713 & 22.3520 & 2.6311 & 21.1567 \\
\hline 50 & 17.6499 & 18.4670 & 21.6581 & 2.9225 & 20.3220 \\
\hline 55 & 16.2582 & 16.6900 & 20.5541 & 3.1010 & 19.1221 \\
\hline 60 & 14.6163 & 14.8221 & 19.0503 & 3.1570 & 17.5723 \\
\hline 65 & 12.7551 & 12.8472 & 17.1841 & 3.1081 & 15.7078 \\
\hline 70 & 10.7286 & 10.7875 & 14.9863 & 2.9309 & 13.5671 \\
\hline 75 & 8.6746 & 8.6982 & 12.5738 & 2.5966 & 11.2740 \\
\hline 80 & 6.6605 & 6.6605 & 9.9625 & 2.1027 & 8.8618 \\
\hline 85 & 4.7460 & 4.7460 & 7.1527 & 1.4663 & 6.3504 \\
\hline
\end{tabular}

Source: own elaboration.

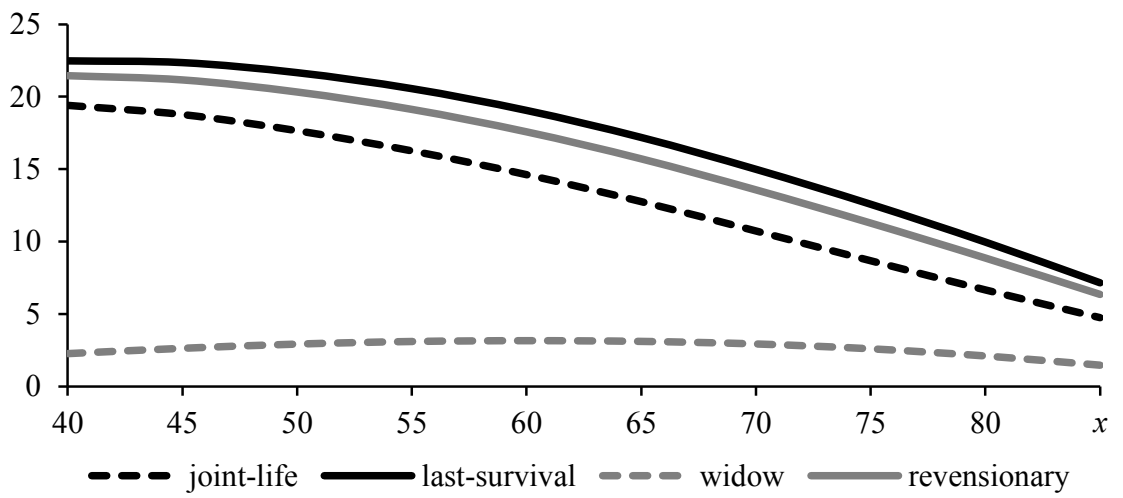

Fig. 2. The values of four pensions for different ages of spouses

Source: own elaboration.

increasing age of spouses. The last-survival annuity gives us the greatest values and the second are the reversionary annuities. But the widows pension behaves differently. First the values of annuity increase and next decrease over 60 years old. The values of a widow's pension are significantly lower than for the other annuities. The values of the joint-life annuity when we do not include divorce are greater, mainly for younger spouses. For $x=40$ the values of it are about $12 \%$ greater and these proportions decrease with an increasing $x$. But for $x \geq 80$ they have the same values. There are no divorces in this case.

Next we investigate the values of annuities for a 50-year-old wife and husband in term of duration of annuities. These values are included in Table 2 and in Figure 3. The widow's pension is understood as annuity 
$a_{x|y ; \bar{n}|}^{W}$ in this case. We can see that they increase with age, but for the joint-life and reversionary annuities and for duration greater than 30 the growth is weaker. The graphs are concave in this case, but for the widow pension we have convex graphs, near linear. The values of the joint-life and reversionary annuities are similar.

Table 2. The values of four pensions for 50-year-old spouses and for different durations of annuities

\begin{tabular}{|r|r|c|c|c|}
\hline$n$ & Joint-life & Last-survival & Widow & Reversionary \\
\hline 5 & 4.4266 & 4.4949 & 0.0521 & 4.4934 \\
\hline 10 & 8.0193 & 8.2765 & 0.1978 & 8.1908 \\
\hline 15 & 10.9131 & 11.4802 & 0.4373 & 11.2071 \\
\hline 20 & 13.2066 & 14.2009 & 0.7669 & 13.6037 \\
\hline 25 & 14.9612 & 16.4945 & 1.1844 & 15.4439 \\
\hline 30 & 16.2207 & 18.3897 & 1.6774 & 16.7725 \\
\hline 35 & 17.0341 & 19.8926 & 2.2065 & 17.6388 \\
\hline 40 & 17.4720 & 20.9832 & 2.7009 & 18.1133 \\
\hline
\end{tabular}

Source: own elaboration.

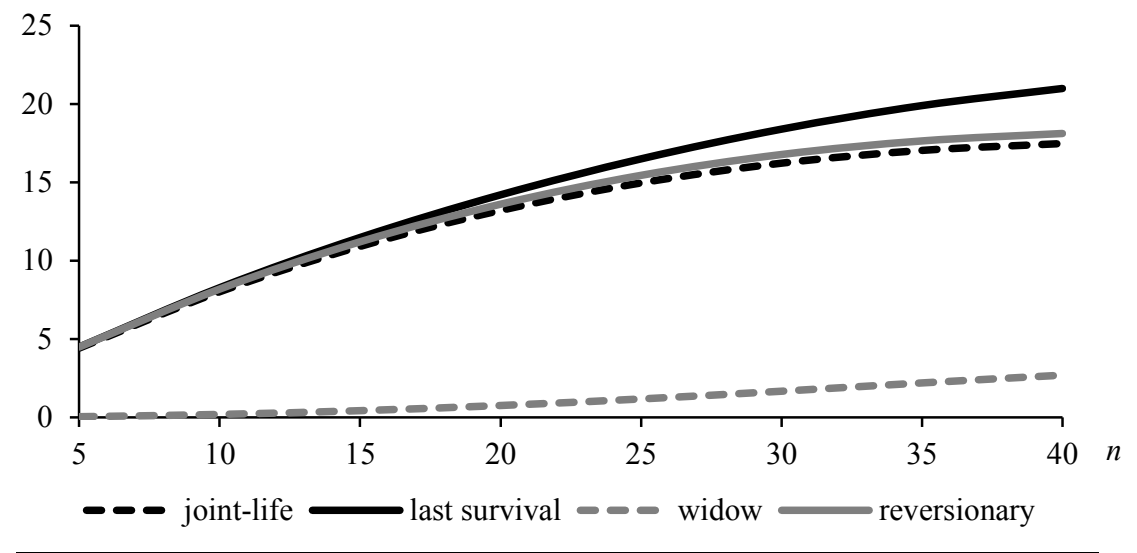

Fig. 3. The values of four pensions for 50year-old spouses and for different durations of annuities

Source: own elaboration.

In Table 3 and Figure 4 we present the values of these four pensions for the spouses in which the wife is 60 years old. The age of husband $x$ is changing from 55 to 70 years and $n=\infty$. We can see that the values of three pensions: joint-life, last-survival and reversionary, decrease with the age of the spouse, but for the widow's pension we have an increase in these values. 
Table 3. The values of four annuities for a 60 -year-old wife and for different ages of the husband

Nr 16(22)

\begin{tabular}{|l|c|c|c|c|}
\hline$x$ & Joint-life & Last-survival & Widow & Reversionary \\
\hline 55 & 15.5274 & 19.6825 & 2.3398 & 18.2974 \\
\hline 56 & 15.3644 & 19.5541 & 2.4869 & 18.1576 \\
\hline 57 & 15.1924 & 19.4265 & 2.6415 & 18.0151 \\
\hline 58 & 15.0107 & 19.2999 & 2.8043 & 17.8702 \\
\hline 59 & 14.8188 & 19.1745 & 2.9760 & 17.7226 \\
\hline 60 & 14.6163 & 19.0503 & 3.1570 & 17.5723 \\
\hline 61 & 14.3741 & 18.8153 & 3.3476 & 17.3921 \\
\hline 62 & 14.1200 & 18.5679 & 3.5451 & 17.2080 \\
\hline 63 & 13.8541 & 18.3072 & 3.7492 & 17.0199 \\
\hline 64 & 13.5765 & 18.0324 & 3.9596 & 16.8277 \\
\hline 65 & 13.2878 & 17.7430 & 4.1756 & 16.6315 \\
\hline 66 & 12.9882 & 17.4381 & 4.3966 & 16.4311 \\
\hline 67 & 12.6785 & 17.1172 & 4.6215 & 16.2263 \\
\hline 68 & 12.3592 & 16.7797 & 4.8494 & 16.0172 \\
\hline 69 & 12.0310 & 16.4253 & 5.0794 & 15.8034 \\
\hline 70 & 11.6945 & 16.0531 & 5.3099 & 15.5846 \\
\hline
\end{tabular}

Source: own elaboration.

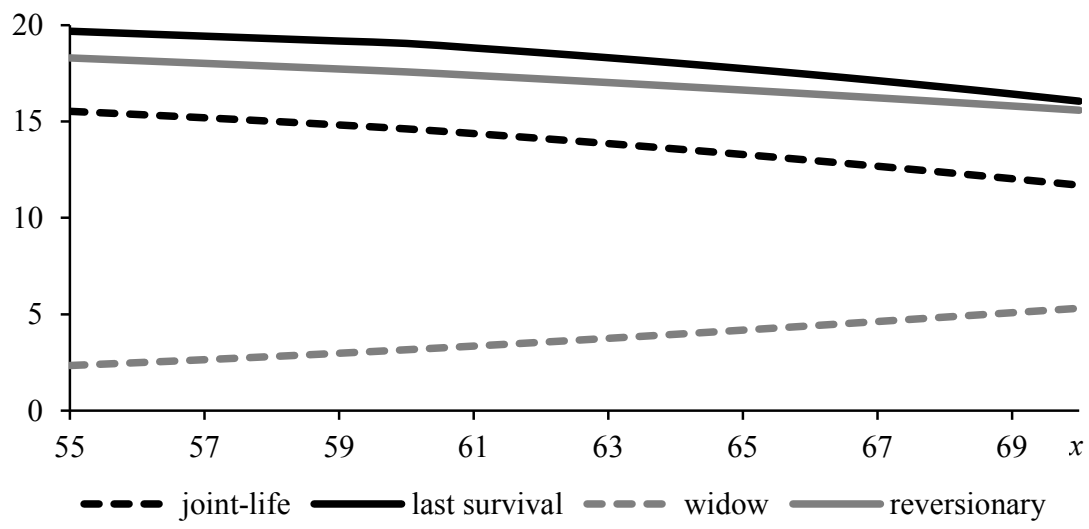

Fig. 4. The values of four annuities for a 60 -year-old wife and for different ages of the husband

Source: own elaboration.

The next part of our analyzes is devoted to the reversionary annuity. We investigate the value of this annuity for different values of the reduction factor $R$. Table 4 shows these values. We can see that the values of the reversionary annuity increases with the growth of parameter $R$, which is a linear growth. 
Table 4. The values of reversionary annuity for 60 -year-old spouses and for different values of reduction factor $R$

\begin{tabular}{|c|c|c|c|}
\hline$R$ & Reversionary & $R$ & Reversionary \\
\hline 0 & 14.6163 & 0.6 & 17.2767 \\
\hline 0.1 & 15.0597 & 0.7 & 17.7201 \\
\hline 0.2 & 15.5031 & 0.8 & 18.1635 \\
\hline 0.3 & 15.9465 & 0.9 & 18.6069 \\
\hline 0.4 & 16.3899 & 1 & 19.0503 \\
\hline 0.5 & 16.8333 & & \\
\hline
\end{tabular}

Source: own elaboration.

Next we analyze the influence of the age difference between the wife and husband on the values of these pensions. We study three cases: wife is older $(x=y-5)$, wife and husband are of the same age $(x=y)$ and husband is older $(x=y+5)$. For the joint-life annuity, see Figure 5a, the first case $(x=y-5)$ gives us the greatest values of annuity for every age of wife $y$, but the values of this annuity in the third case $(x=y+5)$ are the smallest. We obtain a similar situation for last-survival, see Figure 5b, and reversionary annuities, see Figure 5d.

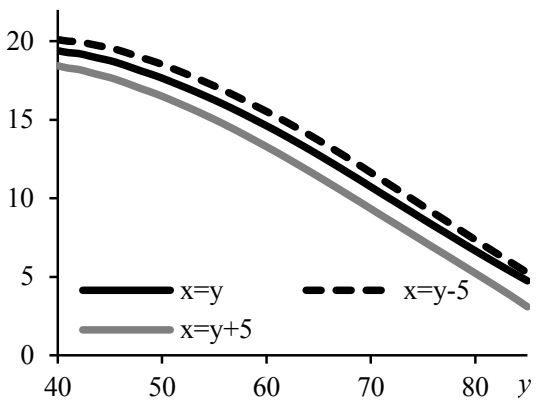

a) joint-life



c) widow

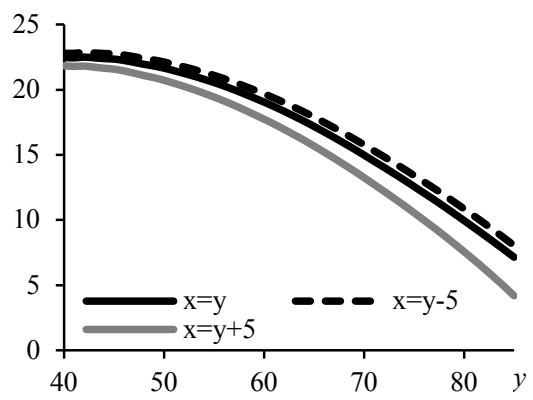

b) last-survival

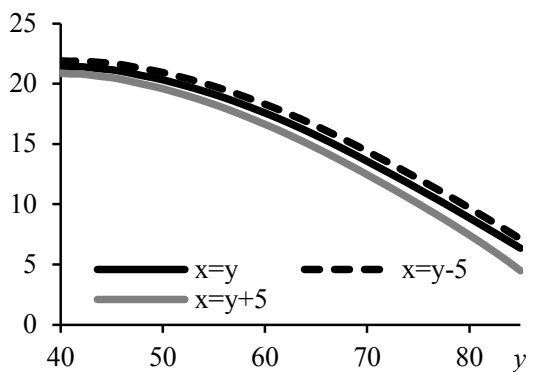

d) reversionary

Fig. 5. The values of annuities for three age differences between wife and husband and the different ages of the wife

Source: own elaboration. 
We have another situation for the widow's pension. The third case $(x=y+5)$ gives us the greatest values of annuity and the first case $(x=y-5)$ the smallest values for every age of wife. First these values grow and next for the age of a wife greater than 60 , they decrease.

\section{Summary}

We investigated marriage insurance allowing for the dependence between the lifetimes of spouses and taking into account the divorces in contrast to other similar papers. We estimated the Markov forces of transition and we derived the actuarial values of the four annuities using real data from Lower Silesia.

We studied several cases. We analyzed the values of such premiums for different ages of spouses at the start of the contracts, for different durations of annuities and for different ages of the husband when the wife is 60 years old. We also investigate these values for age differences between the wife and husband and for different values of the reduction factor in the reversionary annuity. The values of this annuity increases with the growth of this parameter. We can see that the joint-life, the last-survival and the reversionary annuity behave similarly, in contrast to the widow's pension. For instance, the values of these pensions decreases with the growing ages of the spouses at the start of the contracts, but the values of the widow's pension first grow and next decrease.

We also consider the comparison with the non-divorce case. The values of the joint-life annuity when we do not include divorce are greater than when we are considering divorce. The differences are important for the younger spouses.

\section{References}

Denuit M., Dhaene J., Le Bailly de Tilleghem C., Teghem S., 2001, Measuring the impact of a dependence among insured lifelengths, Belgian Actuarial Bulletin, vol. 1(1), pp. 18-39.

Gerber H.U., 1995, Life Insurance Mathematics, Springer, Berlin.

Heilpern S., 2011, Wyznaczanie wielkości renty w zależnych grupowych ubezpieczeniach na życie, Prace Naukowe UE Wrocław, vol. 230, pp. 30-48.

Heilpern S., 2015, Dependent Structure Induced by Markov Chain in the Multiple Life Insurance, Proceedings of 18th AMSE, Czech Republic, Jindrichuv Hradec, http://amse2015.cz/doc/Heilpern.pdf.

Luciano E., Spreeuw J., Vigna E., 2016, Spouses' dependence across generations and pricing impact on reversionary annuities, Risks, vol. 4, pp. 2-18. 
Norberg R., 1989, Actuarial analysis of dependent lives, Bulletin de l'Association Suisse des Actuaries, vol. 40, pp. 243-254.

Wolthuis H., 1994, Life Insurance Mathematics - The Markovian Model, CAIRE Nr 16(22) Education Series 2, CARIE, Brussels.

Wolthuis H., van Hoeck L., 1986, Stochastic models for life contingencies, Insurance: Mathematics and Economics, pp. 217-254.

\section{UBEZPIECZENIA MAŁŻEŃSKIE}

\section{UWZGLĘDNIAJĄCE ZALEŻNOŚĆ ORAZ ROZWODY}

Streszczenie: Artykuł dotyczy małżeńskich kontraktów ubezpieczeniowych dopuszczających zależność długości życia małżonków. Struktura zależności opisana jest pięciostanowym procesem Markowa. Jeden stan dotyczy rozwodów, które nie były uwzględniane we wcześniejszych pracach. Czyni to artykuł bardziej realistycznym. Cztery renty małżeńskie były opisane i analizowane: wspólnego życia, ostatniego przeżywającego, wdowia oraz dziedziczna. Rozpatrywany był też przykład bazujący na rzeczywistych danych z 2011 roku dotyczących Dolnego Śląska. Wartości rent zostały wyznaczone i przeprowadzono ich analizę. Rozpatrzono pięć przypadków. Zbadano wpływ wieku małżonków i czasu trwania ubezpieczenia na wartości tych rent. Analizowano też przypadek dotyczący renty dziedzicznej o współczynniku redukcji $R=2 / 3$. Dokonano również porównania z przypadkiem nieuwzględniającym rozwodów.

Słowa kluczowe: ubezpieczenia małżeńskie, zależność, łańcuch Markowa, renty, rozwody. 